\title{
Impaired Interferon Production and Natural Killer Cell Activation in Patients with the Skin Cancer-prone Disorder, Xeroderma Pigmentosum
}

\author{
Anthony A. Gaspari, ** Thomas A. Fleisher, " and Kenneth H. Kraemer" \\ ${ }^{*}$ Dermatology Branch and "Laboratory of Molecular Carcinogenesis, National Cancer Institute, and ${ }^{\S}$ Warren G. Magnuson Clinical \\ Center, National Institutes of Health, Bethesda, Maryland 20892; and ${ }^{\ddagger}$ Department of Dermatology, \\ University of Rochester School of Medicine and Dentistry, Rochester, New York 14642
}

\begin{abstract}
Xeroderma pigmentosum (XP) is a rare autosomal recessive disorder with sun sensitivity, markedly increased skin cancer susceptibility, and defective DNA repair without consistently identified symptoms of immune deficiency. We examined natural killer (NK) cell activity and interferon production in peripheral blood lymphocytes (PBL) of eight XP patients who had multiple primary skin cancers. The XP patients had normal numbers of $T$ cells and NK cells, as well as normal lymphokineactivated killer cell activity and normal tumor necrosis factor- $\alpha$ production. Unstimulated NK cell function was $40 \%$ of normal controls in five XP patients, but was normal in three other XP patients. However, PBL from all the XP patients tested showed no enhancement of NK activity by the interferon inducer, polyinosinic acid:polycytidilic acid (polyIC) but enhancement by interferon- $\alpha$ was normal, suggesting an impairment in interferon production. Parallel studies in non-XP skin cancer patients revealed that both unstimulated and polyIC-enhanced NK activity were normal. Further investigation using PBL from XP patients revealed that the production of interferon- $\gamma$ after stimulation with interferon inducers (polyIC, interleukin 2, or K562 tumor cells) was $13-43 \%$ of normals. These data indicate that XP lymphocytes have a defect in production of interferons and suggest that defective interferon production, as well as DNA repair defects, may play an important role in the susceptibility of XP patients to skin cancer. (J. Clin. Invest. 1993. 92:1135-1142.) Key words: cutaneous neoplasms • cytokine defect • interferon inducer • natural immunity • tumor surveillance
\end{abstract}

\section{Introduction}

A normal immune system is thought to be critical in the host's surveillance against the development of neoplasia. Natural killer (NK $)^{1}$ cells may provide an important effector mechanism in this network, and there is abundant experimental evi-

1. Abbreviations used in this paper: LAK, lymphokine-activated killer; LU, lytic units; NK, natural killer; polyIC, polyinosinic acid:polycytidilic acid; XP, xeroderma pigmentosum.

This study was presented in part at the 51st Annual Meeting of The Society for Investigative Dermatology in Washington, DC, May 1990.

Dr. Gaspari's present address is Department of Dermatology, University of Rochester School of Medicine and Dentistry, Box 697, 601 Elmwood Avenue, Rochester, NY 14642.

Address reprint requests to Dr. Gaspari.

Received for publication 25 February 1993 and in revised form 9 April 1993.

The Journal of Clinical Investigation, Inc.

Volume 92, September 1993, 1135-1142 dence that these cells can prevent the growth and metastasis of transplanted tumors in animal model systems (1-11). Clinical observations concerning depressed NK cell function in patients with advanced malignancies are consistent with the concept that such cells may play an important role in immune surveillance $(12,13)$. However, the role of NK cells in the prevention of cancer development has not been established.

Xeroderma pigmentosum (XP) is a rare autosomal recessive disorder characterized by sun sensitivity, increased freckling, and a $>1,000$-fold increased frequency of skin cancers (14-17). Studies of patients' cells have revealed DNA repair defects which are associated with reduced cell survival and increased cell mutations after exposure to ultraviolet radiation (14-17).

In addition to the DNA repair defects found in all XP patients, there have been a variety of cellular immune abnormalities noted in isolated XP patients: decreased delayed-type hypersensitivity reactions (impaired responses to intradermal recall antigens and decreased dinitrochlorobenzene sensitization ), decreased T-cell proliferative responses to mitogens, decreased CD4/CD8 ratio, and one report each of severe combined immunodeficiency and systemic lupus erythematosus $(15,18-25)$. Norris et al. $(26,27)$ reported decreased NK cell activity in five patients with XP, when compared to normal controls, and in patients with trichothiodystrophy or Cockayne syndrome. These investigators postulated that the decreased NK cell function in patients with XP results in defective host immune surveillance that is permissive for the development of skin cancers.

In this study, we report that XP patients are heterogeneous in their expression of NK cell function. In contrast to the previous reports of Norris et al. $(26,27)$, our studies show no correlation between NK activity and skin cancer. However, NK cell activity from all XP patients tested failed to show enhancement by polyinosinic acid:polycytidilic acid (polyIC) and XP PBL had a marked impairment in interferon production after stimulation with IFN inducers. Similar assays in nonXP patients with multiple skin cancers were normal, indicating that the defects noted in XP PBL were not secondary to the presence of multiple skin cancers.

\section{Methods}

Patients. Eight patients with XP were studied (Table I). All of these patients had extensive actinic damage and multiple skin cancers resulting from exposure to naturally occurring ultraviolet radiation. Clinical features and/or DNA repair studies of these patients have been published $(14,28)$. Patients 1,5 , and 6 had XP-associated neurological abnormalities including deafness and mental retardation (14-16, 28). Except for the clinical abnormalities of XP, the patients were healthy with no evidence of metastatic disease. Five of the patients (patient numbers $1,2,3,5$, and 7 ) received oral isotretinoin $0.5-1.0 \mathrm{mg} / \mathrm{kg}$ per 


\begin{tabular}{|c|c|c|c|c|c|}
\hline \multirow[b]{2}{*}{ Patient* } & \multirow[b]{2}{*}{$\operatorname{Age}^{t} / \operatorname{Sex}$} & \multirow[b]{2}{*}{ Skin cancers } & \multicolumn{3}{|c|}{ Absolute lymphocyte counts } \\
\hline & & & T cells" & NK cells' & B cells** \\
\hline & $y r$ & & & $/ \mathrm{mm}^{3}$ & \\
\hline $1^{\ddagger \ddagger}$ & $25 / \mathrm{F}$ & 50 & 2005 & 370 & 220 \\
\hline 2 & $18 / \mathrm{F}$ & $81(1)^{58}$ & 1203 & 70 & 245 \\
\hline 3 & $24 / \mathrm{M}$ & $50(1)$ & 678 & 92 & 358 \\
\hline 4 & $45 / M$ & 33 & 1825 & 105 & $\mathrm{NT}^{\|\|} \|$ \\
\hline 5 & $16 / \mathrm{M}$ & 46 & 1209 & 59 & 272 \\
\hline $6^{n}$ & $10 / \mathrm{F}$ & 22 & 1198 & 134 & 148 \\
\hline 7 & $22 / \mathrm{M}$ & $170(3)$ & 2726 & 163 & NT \\
\hline $8^{* * *}$ & $45 / F$ & $>200(20)$ & 2067 & 157 & 246 \\
\hline \multicolumn{6}{|l|}{ Normal range } \\
\hline$($ mean \pm SD) & & & $1484 \pm 499$ & $263 \pm 204$ & $245 \pm 153$ \\
\hline
\end{tabular}

\footnotetext{
* Identification numbers 1-7 as in reference 28 . Age as of January 1991 . Number of histologically confirmed basal cell carcinomas or squamous cell carcinomas as of January 1991. "Number of CD3-positive cells $/ \mathrm{mm}^{3}$. ' Number of CD16-positive cells/mm . $^{* *} \mathrm{Number}$ of CD20-positive cells $/ \mathrm{mm}^{3}$. ${ }^{\ddagger} \mathrm{XP12Be}$ (complementation group A) from reference 14 . Number of histologically confirmed primary cutaneous melanomas. "I " Not tested. "Complementation group C (Kraemer et al., unpublished observation). *** XP1 BE (complementation group C) from reference 14 .
}

d during a portion of the study period for cancer chemoprevention (28). Normal controls were healthy laboratory personnel.

Five non-XP skin cancer control patients were also studied (Table II). These non-XP skin cancer control patients had no known DNA repair defect, and were selected on the basis of having had at least five histologically proven skin cancers (basal cell or squamous cell carcinomas). These patients had moderate to severe actinic damage (freckling, skin wrinkling, actinic keratosis), adult onset skin cancer, and no history of abnormal photosensitivity. All five skin cancer control patients had skin type I, with a history of easy sunburning and a lack of tanning in response to naturally occurring sun exposure.

Lymphocyte phenotype analysis. The numbers of T cells, NK cells, and B cells from XP patients were measured by flow cytofluorometric analysis utilizing conjugated (fluorescein or phycoerythrin) $\mathrm{mAbs}$ or unconjugated $\mathrm{mAbs}$ followed by fluoresceinated goat anti-mouse IgG. The mAbs were directed against $\mathrm{T}$ cell antigens (CD4, CD8, $\mathrm{T}$ cell receptors $(\alpha / \beta$ or $\gamma / \delta), \mathrm{CD} 3, \mathrm{CD} 2, \mathrm{CD} 25)$, NK antigens (CD56, CD57, CD16), B cell antigens (CD20, CD19), and activation antigens (HLA-DR) (All mAbs were purchased from Becton-Dickinson \& Co., Mountain View, CA).

Assay of constitutive NK cell activity. NK cell activity was evaluated using ${ }^{51} \mathrm{Cr}$ release after a 4-h incubation of the effector and labeled target cells (29). Briefly, PBL were separated from whole blood using lymphoprep gradients (Nycomed, Oslo, Norway). PBL isolated at the

Table II. Characteristics of Non-XP Skin Cancer Patients Studied

\begin{tabular}{ccc}
\hline Patient & Age/Sex* & Skin cancers \\
\hline & $y r$ & \\
1 & $46 / \mathrm{M}$ & 5 \\
2 & $52 / \mathrm{M}$ & 8 \\
3 & $56 / \mathrm{M}$ & 6 \\
4 & $72 / \mathrm{M}$ & 10 \\
5 & $64 / \mathrm{M}$ & 6 \\
\hline
\end{tabular}

* Age as of May 1992. ${ }^{\ddagger}$ Cumulative frequency of skin cancers as of May 1992 (basal and squamous cell carcinomas). interface were washed extensively with HBSS containing $1 \%$ FCS and utilized as effector cells. The NK-sensitive tumor cell lines, K562 and MOLT4 (American Type Culture Collection, Rockville, MD) were labeled with ${ }^{51} \mathrm{Cr}$ using standard methods (29). Variable numbers of effector cells were added to $1 \times 10^{5}$ target cells suspended in $200 \mathrm{ml}$ of complete medium (RPMI 1640 supplemented with $10 \%$ FCS, $100 \mathrm{U} /$ $\mathrm{ml}$ penicillin, $100 \mu \mathrm{g} / \mathrm{ml}$ streptomycin, $0.25 \mu \mathrm{g} / \mathrm{ml}$ fungizone, $1 \mu \mathrm{g} / \mathrm{ml}$ glutamine) with $1 \mu \mathrm{g} / \mathrm{ml}$ indomethacin and incubated for $4 \mathrm{~h}$ at $37^{\circ} \mathrm{C}$ in a $5 \% \mathrm{CO}_{2}$ atmosphere. In these experiments the effector to target cell (E/T) ratios ranged from $4: 1$ to $64: 1$. At the end of the incubation, cell-free supernatants were harvested and ${ }^{51} \mathrm{Cr}$ release was assayed utilizing gamma counting. The results are expressed as the percent of lysis based on a $100 \%$ target cell lysis value obtained after detergent addition to the target cells. Indomethacin was included in the culture medium to suppress endogenous or polyIC-induced prostaglandin production (30).

Lymphokine-activated killer ( $L A K$ ) cell assay. PBL were cultured at $5 \times 10^{6} \mathrm{cells} / \mathrm{ml}$ in complete medium in the presence of $100 \mathrm{U} / \mathrm{ml}$ recombinant interleukin 2 (rIL-2) (Amgen Inc., Thousand Oaks, CA) for $48 \mathrm{~h}$ at $37^{\circ} \mathrm{C}$ in a $5 \% \mathrm{CO}_{2}$ atmosphere. These cells were then washed extensively and utilized as LAK effector cells (31). Several E/T ratios were used in a 4-h incubation with ${ }^{51} \mathrm{Cr}$-labeled (NK cell resistant) Burkitt's lymphoma Daudi cells (American Type Culture Collection), and ${ }^{51} \mathrm{Cr}$ release was measured as noted in the previous section.

Calculation of lytic units $(L U)$. The data generated from the ${ }^{51} \mathrm{Cr}$ release assays for spontaneous NK and LAK cell activity were plotted using logarithmic scales for both the ordinate and the abscissa. Each data set was represented by a regression line connecting those data points lying in the linear portion of the curve. The number of effector cells required to lyse $30 \%$ of the target cells (LU30) was calculated from these regression lines (1). The number of LU30/10 6 cells was calculated by dividing $10^{6}$ by LU30. For statistical analysis of LU, we compared the mean, aggregate $\mathrm{LU}$ of calculated from each individual patient's cytotoxicity assay with K562, MOLT4, or Daudi cell targets. The mean aggregate LU from XP patients or skin cancer controls was compared to normal controls using the methods described in reference 32.

Assay for the enhancement of NK cell activity. Isolated PBL were incubated with pharmacologic agents (either IFN- $\alpha$ or polyIC) (Calbiochem Corp., San Diego, CA) or medium alone (control) for $2 \mathrm{~h}$ at $37^{\circ} \mathrm{C}$ in a $5 \% \mathrm{CO}_{2}$ atmosphere and washed three times. The preincubated cells were then mixed with ${ }^{51} \mathrm{Cr}$-labeled K562 cell targets for $4 \mathrm{~h}$. 
Percent enhancement of NK activity was determined by the following formula: [(NK activity of leukocytes incubated with pharmacologic agents) - (NK activity of leukocytes incubated with medium alone)]/ (NK activity of leukocytes incubated with medium alone) $\times 100 \%$. The assay for the enhancement of NK activity was performed at an 8:1 E/T ratio.

$T N F-\alpha$ immunoassay. A commercially available assay for TNF- $\alpha$ (Biokine Test Kit, T Cell Sciences, Cambridge, MA) was utilized to detect immunoreactive TNF- $\alpha$ in culture supernatants. This ELISA detects TNF- $\alpha$ in supernatants having activities ranging from 10 to $1,500 \mathrm{pg} / \mathrm{mL}$.

$T N F-\alpha$ bioassay. Adherent WEHI 164 mouse fibrosarcoma cells (American Type Culture Collection) treated with $100 \mathrm{mg} / \mathrm{ml}$ actinomycin D (Dactinomycin, Merck Sharp \& Dohme, West Point, PA) for $3 \mathrm{~h}$ at $37^{\circ} \mathrm{C}$ were used as the target cells for the TNF- $\alpha$ bioassay (32). These cells were then washed three times with HBSS, suspended with $0.25 \%$ trypsin/EDTA, and washed three times again, and $10^{6}$ cells were labeled with ${ }^{51} \mathrm{Cr}$ for $1 \mathrm{~h}$ at $37^{\circ} \mathrm{C}$. After additional washing, the ${ }^{51} \mathrm{Cr}$-labeled cells ( $10^{4}$ per well of a microtiter plate) were then incubated with recombinant TNF- $\alpha$ containing supernatants to establish a dose-response curve. In parallel, the treated WEHI 164 cells were incubated with serially diluted unknown supernatants. After a 6-h incubation with the standards or unknown supernatants, ${ }^{51} \mathrm{Cr}$ release was assayed. One unit of lytic activity is that dose of TNF- $\alpha$ that induces $50 \%$ maximal lysis of WEHI 164.

IFN- $\gamma$ activity bioassay. Assessment of IFN- $\gamma$ production used peripheral blood lymphocytes after exposure to the IFN inducer polyIC for $2 \mathrm{~h}$, or continuous exposure to IL- 2 or K562 cells for $26 \mathrm{~h}$. Culture supernatants after these stimuli were assayed for the presence of IFN- $\gamma$ utilizing a bioassay (inhibition of viral cytopathic effect induced by vesicular stomatitis virus) performed by M.A. Biofluids (Rockville, MD). Briefly, confluent WISH cells (human amnion-derived cells, American Type Culture Collection) were cultured for $24 \mathrm{~h}$ in a 96-well microtiter plate in the presence of serially diluted supernatants being assayed (unknown). Other WISH cells were cultured in parallel in the presence of different doses of recombinant human IFN- $\gamma$. After this incubation, the cells were washed and medium containing $300 \mathrm{ID}_{50}$ of vesicular stomatitis virus were added to each well. The infected cells were then cultured for another $24 \mathrm{~h}$ ( until the virus controls showed 4+ cytopathic effect), and the wells containing the unknowns or IFN- $\gamma$ standards were assessed microscopically for viral cytopathic effect. The reciprocal of the highest dilution of the unknown that produces $50 \%$ or greater inhibition of the cytopathic effect is considered to be the end point (34).

IFN- $\gamma$ immunoreactivity. An ELISA specific for IFN- $\gamma$ (Amgen Biologicals) was utilized to determine the amount of immunoreactive IFN- $\gamma$ in the culture supernatants. This ELISA detects IFN- $\gamma$ in supernatants with activities ranging from 5 to $100 \mathrm{U} / \mathrm{ml}$.

IFN- $\alpha$ bioassay. For the IFN- $\alpha$ bioassay, cultured PBL were exposed to the IFN inducer polyIC for $2 \mathrm{~h}$ and then washed and cultured for an additional $24 \mathrm{~h}$. The culture supernatants were assayed for the presence of IFN- $\alpha$ by assaying for inhibition of viral cytopathic effect induced by vesicular stomatitis virus (M.A. Biofluids). Briefly, confluent bovine keratinocytes (American Type Culture Collection) in a 96-well microtiter plate were cultured for $24 \mathrm{~h}$ in the presence of serially diluted supernatants being assayed (unknown). Other bovine keratinocytes were cultured in parallel in the presence of known doses of recombinant human IFN- $\alpha$. After this incubation, the cells were washed and medium containing $300 \mathrm{ID}_{\mathbf{5 0}}$ of vesicular stomatitis virus was added to each well. The infected cells were then cultured for another $24 \mathrm{~h}$ at which time the virus controls showed $4+$ cytopathic effect and then the other wells containing the unknowns or IFN- $\alpha$ standards were assessed microscopically for viral cytopathic effect. The reciprocal of the highest dilution of the unknown that produces $50 \%$ or greater inhibition of the cytopathic effect is considered to be the end point (34).

Statistical analysis of data. The data was analyzed for significant differences utilizing Students' $t$ test (32); probability values $<0.05$ were considered significant.
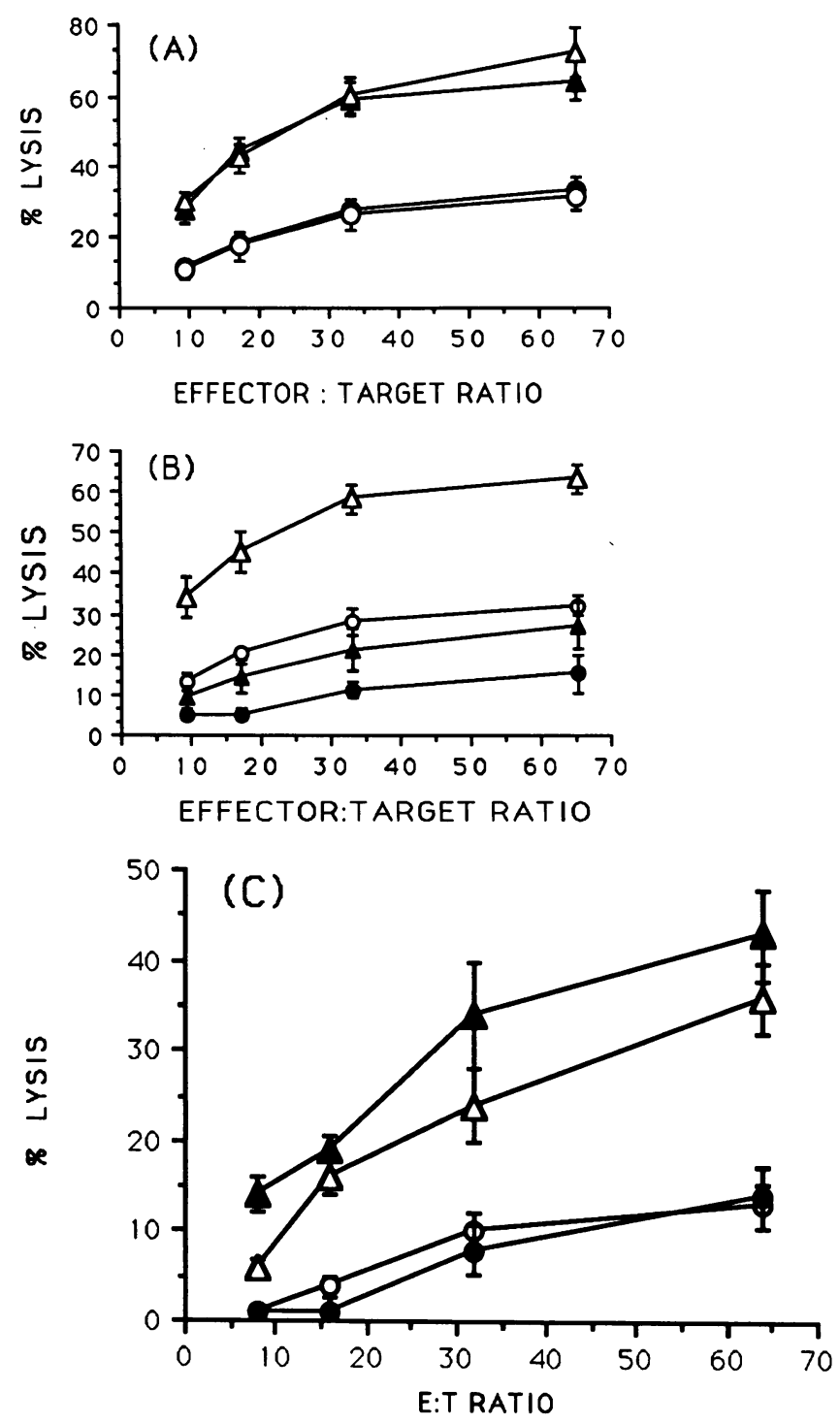

Figure 1. Heterogeneity of endogenous NK cell activity of peripheral blood lymphocytes from XP patients and normal NK cell activity in skin cancer controls. $(A)$ Mean NK activity of three XP patients (patients 3,4, and 7) was the same as five normal controls. $(B)$ Mean NK activity of five XP patients (patients $1,2,5,6$, and 8) was decreased in comparison to six normal controls. ( 0 ) Control effector cells, MOLT4 targets; $(\bullet)$ XP effector cells, MOLT4 targets; $(\Delta)$ control effector cells, K562 targets; ( $\Delta$ ) XP effector cells, K562 targets. $(C)$ Mean NK activity of five non-XP skin cancer patients was the same as normal controls on K562 or MOLT4 targets. (O) control effector cells, MOLT4 target; $(\bullet)$ non-XP skin cancer effector cells, MOLT4 targets; $(\Delta)$ control effector cells, K562 targets; ( $\Delta$ ) non-XP skin cancer effector cells, K562 targets.

\section{Results}

$X P$ patients have normal numbers of lymphocytes. Table I shows the XP patient characteristics and flow cytofluorometric measurements from PBL. The number of T cells, NK cells, and $B$ cells in the peripheral blood of the XP patients were all within the normal range.

$X P$ patients are heterogeneous in their expression of constitutive NK cell activity. Constitutive NK cell activity was assayed on two NK sensitive targets (K562 and MOLT4 cells) utilizing a standard ${ }^{51} \mathrm{Cr}$ release assay (Fig. 1). Three XP pa- 
tients (patient numbers 3,4 , and 7 ) had baseline NK activity equivalent to that of normal controls (Fig. $1 \mathrm{~A}$ ) (For MOLT4 target cells, mean $\mathrm{LU}_{\mathrm{XP}}=11.00 \pm 1.32$, mean $\mathrm{LU}_{\mathrm{Con}}$ $=12.50 \pm 1.04, P=0.10$, not significant; for K562 target cells, mean $\mathrm{LU}_{\mathrm{XP}}=6.00 \pm 1.00$, mean $\mathrm{LU}_{\mathrm{Con}}=6.00 \pm 1.35, P=0.21$, not significant). The baseline NK activity of the remaining five patients (patient numbers $1,2,5,6$, and 8 ) was depressed to $40 \%$ of normal (Fig. $1 B$ ) (For MOLT4 target cells, mean $\mathrm{LU}_{\mathrm{XP}}$ $=0.80 \pm 0.25$, mean $\mathrm{LU}_{\text {Con }}=2.00 \pm 0.58, P=0.05$; for $\mathrm{K} 562$ target cells mean $\mathrm{LU}_{\mathrm{XP}}=1.00 \pm 0.49$ mean $\mathrm{LU}_{\text {con }}$ $=23.20 \pm 10.30, P=0.06)$. This decreased NK activity was noted with either MOLT4 or K562 targets at all E/T ratios assayed, and was reproducible in three separate assays performed on different occasions.

Non-XP skin cancer controls express normal constitutive $N K$ cell activity. To determine whether the observed heterogeneity in constitutive NK cell activity was specific for XP, we assayed NK activity in five normal patients with multiple skin cancers. Although there was a slightly increased lysis of K562 by PBL from skin cancer controls, this was not statistically significant when compared to normal controls. Aggregate, unstimulated NK activity was normal when compared to normal controls with K562 and MOLT4 target cells (Fig. 1 C) (For MOLT4 target cells, mean $\mathrm{LU}_{\mathrm{CA}}=1.00 \pm 0.11$, mean $\mathrm{LU}_{\mathrm{Con}}$ $=1.00 \pm 0.33, P=0.20$; for $\mathrm{K} 562$ target cells, mean $\mathrm{LU}_{\mathrm{CA}}$ $=2.60 \pm 1.07$, mean $\left.\mathrm{LU}_{\mathrm{Con}}=1.70 \pm 0.44, P=0.20\right)$.

$X P$ patients have normal $L A K$ cell activity. We next evaluated the generation of LAK cells with PBL from patients with XP. LAK cell activity of lymphocytes from all six XP patients tested (patient numbers $1,4,5,6$, and 8 ) was normal, regardless of whether their constitutive NK activity was normal or decreased (Fig. 2) (For Daudi cell targets, mean $\mathbf{L U}_{\mathbf{X P}}$ $=15.00 \pm 6.44$, mean $\mathrm{LU}_{\mathrm{Con}}=21.00 \pm 4.00, P=0.20$.)

$T N F-\alpha$ production by XP lymphocytes is normal. To determine whether there were abnormalities in the production of other cytokines that may play a role in the host's antitumor defenses, we assayed TNF- $\alpha$ production in response to rIL-2. Lymphocytes from controls or XP patients were incubated for $24 \mathrm{~h}$ in medium alone or medium containing rIL-2 1,000 U/

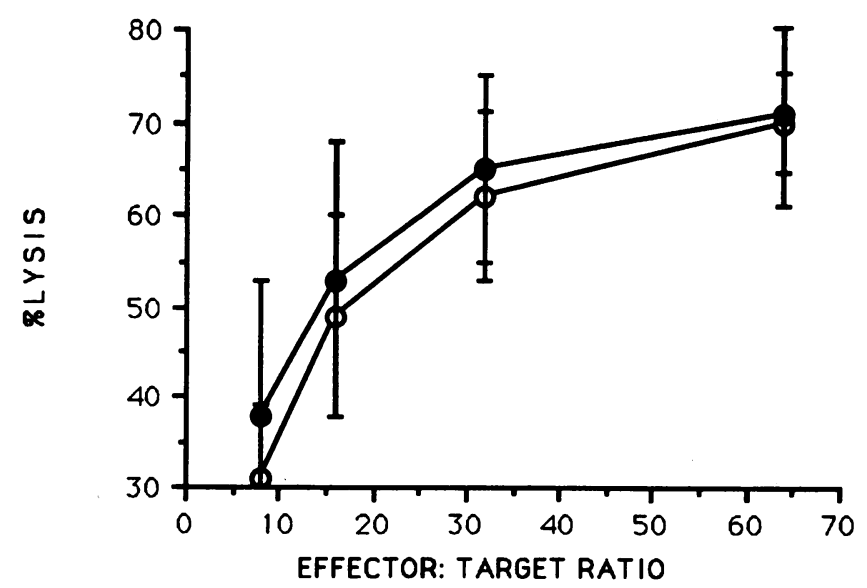

Figure 2. Normal LAK cell activity of peripheral blood lymphocytes from XP patients. Peripheral blood lymphocytes from six XP patients (patients 1, 4, 5, 6, and 8) or six normal controls were cultured with IL-2 $(100 \mathrm{U} / \mathrm{ml})$ for $48 \mathrm{~h}$ and then utilized as effector cells to lyse the NK-resistant ${ }^{51} \mathrm{Cr}$-labeled target Daudi cells. (O) Control LAK cells; (•) XP LAK cells.

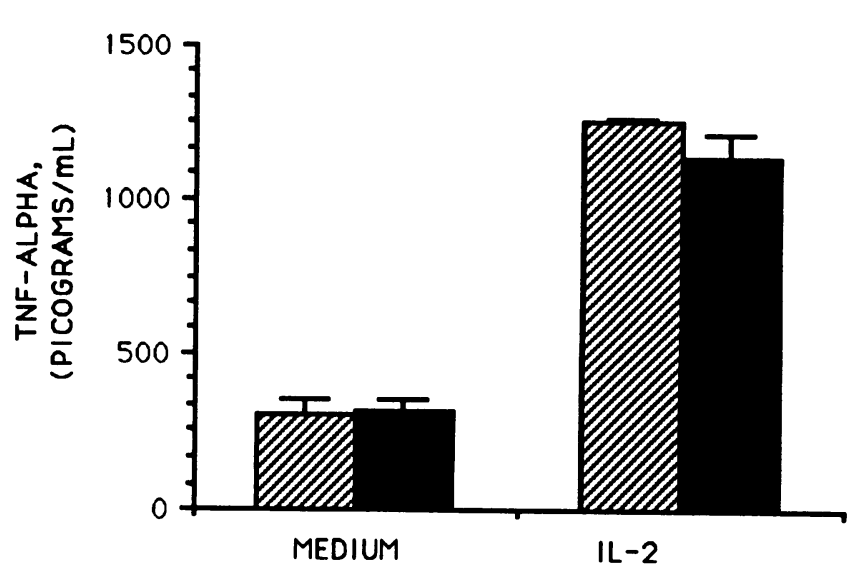

Figure 3. TNF- $\alpha$ production of PBL from XP patients is normal. Lymphocytes from four controls or six XP patients (patients 1, 4, 6, 7 , and 8 ) were cultured for $24 \mathrm{~h}$ in the presence of medium alone (see Methods) or medium that contained rIL-2 1,000 U/ml. At the end of the incubation period, supernatants were collected and assayed for TNF- $\alpha$ by ELISA (see Methods). (ø) Control PBL; ( $\bullet$ ) XP PBL.

$\mathrm{ml}$, the supernatants were then collected and evaluated for TNF- $\alpha$ by immunoassay (Fig. 3). In response to IL-2, PBL from XP patients produced normal amounts of TNF- $\alpha$ (mean [TNF- $\alpha$ ] $/ 10^{6}$ cells from patients $1,4,6,7$, and 8 was equivalent to normal controls, $P=0.15$ ). Evaluation of TNF- $\alpha$ production by bioassay revealed similar response patterns of PBL from XP and controls (data not shown).

Impaired enhancement of NK cell activity from XP patients in response to polyIC. We modified the $\mathrm{NK}$ cell assay as previously described to determine whether there were abnormalities in the capacity of pharmacologic agents to enhance the lytic activity of NK cells from XP patients $(35,36)$. We tested for pharmacologic enhancement of cytotoxicity after a 2-h preincubation with polyIC using the cells from two XP patients with normal constitutive activity (patients 4 and 7), three XP patients with decreased constitutive activity (patients 1,5 , and 8), and four normal controls (Fig. $4 \mathrm{~A}$ ).

After this pretreatment, control NK cells increased their cytotoxic activity substantially (Fig. $4 A$ ). In contrast, NK cells from all five XP patients showed a profound impairment in their response to polylC at all doses assayed $(1,000 \mu \mathrm{g} / \mathrm{ml}, P$ $=0.01 ; 100 \mu \mathrm{g} / \mathrm{ml}, P=0.04 ; 10 \mu \mathrm{g} / \mathrm{ml}, P=0.02)$. There were no significant differences in response to polyIC in PBL from XP patients with normal constitutive NK activity (patients 4 and 7) when compared to the XP patients with decreased constitutive NK activity (patients 1, 5, and 8); both groups demonstrated a similarly profound defect in their enhancement of NK activity by polyIC.

To determine whether the impaired NK activation response to polyIC was specific for XP, we also assayed PBL from three different skin cancer control patients for the enhancement of NK activity in response to pharmacologic agents. There was a dose dependent increase in NK activity in PBL from non-XP skin cancer control patients that was equivalent to that of normal controls (Fig. $4 B$ ).

Enhancement of NK cell activity by IFN. XP and control PBL were also treated with the NK enhancer, IFN- $\alpha$ (Fig. 5). Assay of the response by peripheral blood lymphocytes from five XP patients revealed a decreased augmentation of NK activity when compared to normal three controls, but this differ- 


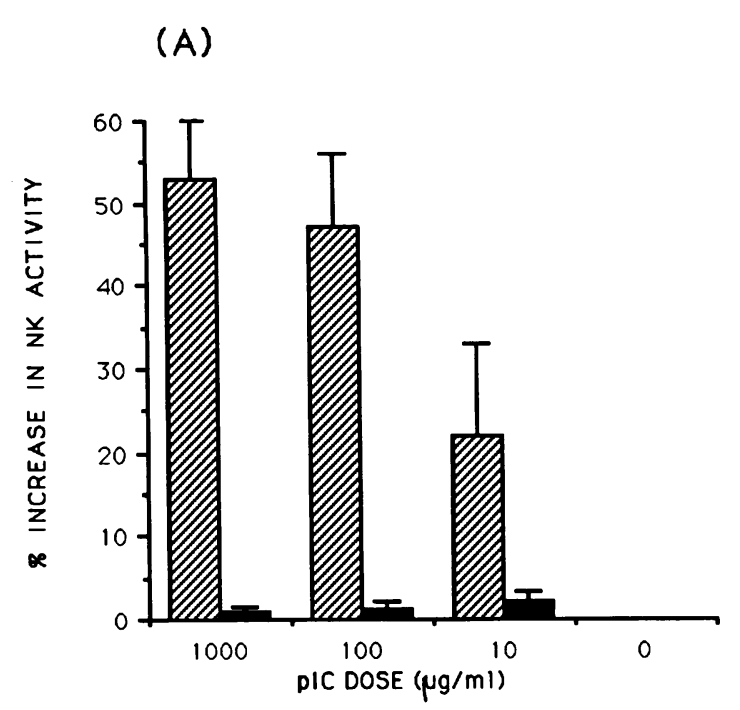

(B)

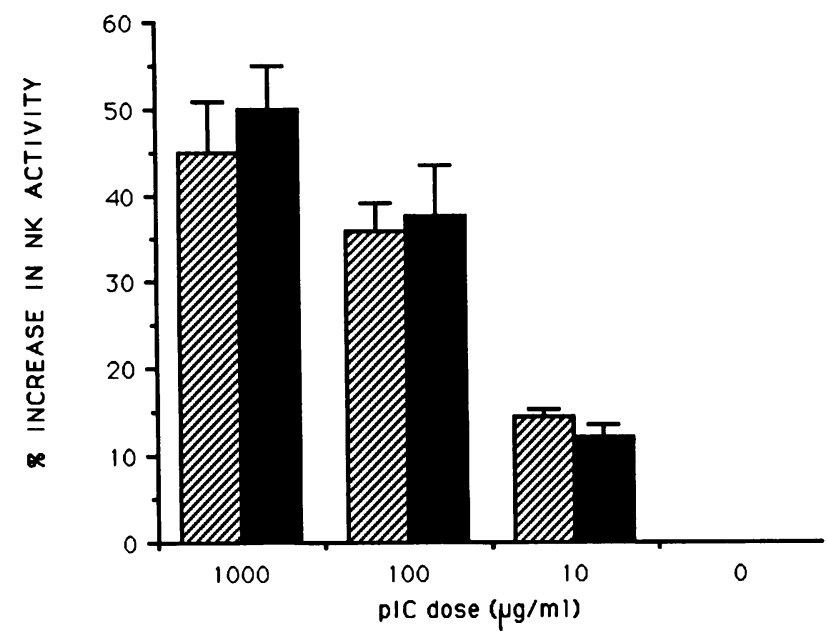

Figure 4. PolyIC enhancement of NK activity of PBL from XP, non$\mathrm{XP}$ skin cancer patients, and normal controls. After a 2-h pulse incubation with different doses of polyIC or medium alone, lymphocytes from five XP patients or three non-XP skin cancer controls and three normal controls were washed extensively and utilized as effector cells to lyse ${ }^{51} \mathrm{Cr}$-labeled K562 cells. Percent increase in mean NK activity for five XP patients (patients 1, 4, 5, 7, and 8) and six controls is shown (see Methods for formula used). Enhancement of NK by polyIC in $A$ ( ) control or ( $\square$ ) XP effector cells; and in $B(\square)$ control or (匹) non-XP skin cancer patients.

ence was not statistically significant. Of the three XP patients with decreased constitutive NK activity (patients 1, 5, and 8), the IFN- $\alpha$ treatment boosted NK activity to a level of that of normal controls (patient 8); in the other two (patients 1 and 5 ), IFN- $\alpha$ treatment did not completely normalize NK activity when compared to controls (patient $1,0 \%$ of control; patient 5 , $50 \%$ of control).

Impaired IFN production by XP lymphocytes. The enhancement of NK activity by polyIC is thought to be mediated by stimulation of IFN production, which then acts on NK cells in an autocrine manner. Since lymphocytes from XP patients failed to respond to polyIC, we assayed interferon production by XP lymphocytes in response to polyIC. Lymphocytes from

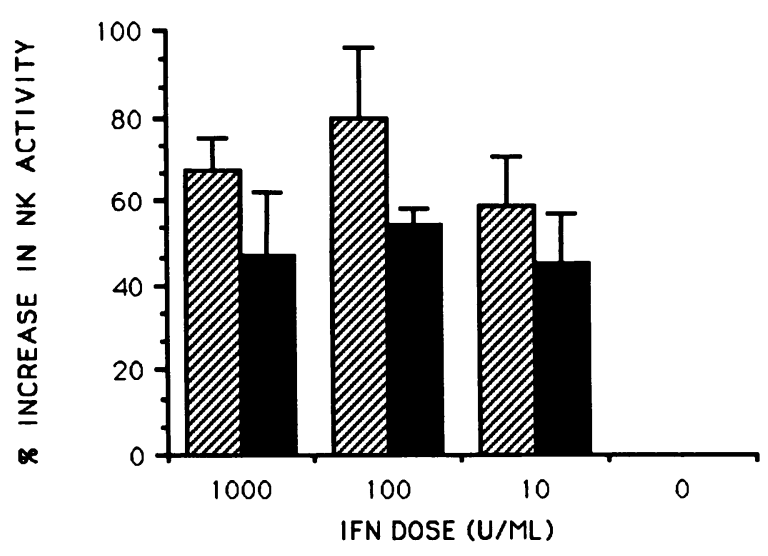

Figure 5. Enhancement of NK activity by IFN- $\alpha$ is normal in XP lymphocytes. After a 2-h pulse incubation with different doses of IFN- $\alpha$ or medium alone, lymphocytes from five XP patients and three normal controls were washed extensively and utilized as effector cells to lyse ${ }^{51} \mathrm{Cr}$-labeled K562 cells. Percent increase in mean NK activity for five XP patients (patients 1, 4, 5, 7, and 8) and three controls is shown (see Methods for formula used). (四) Control effector cells; ( $\bullet$ ) XP effector cells.
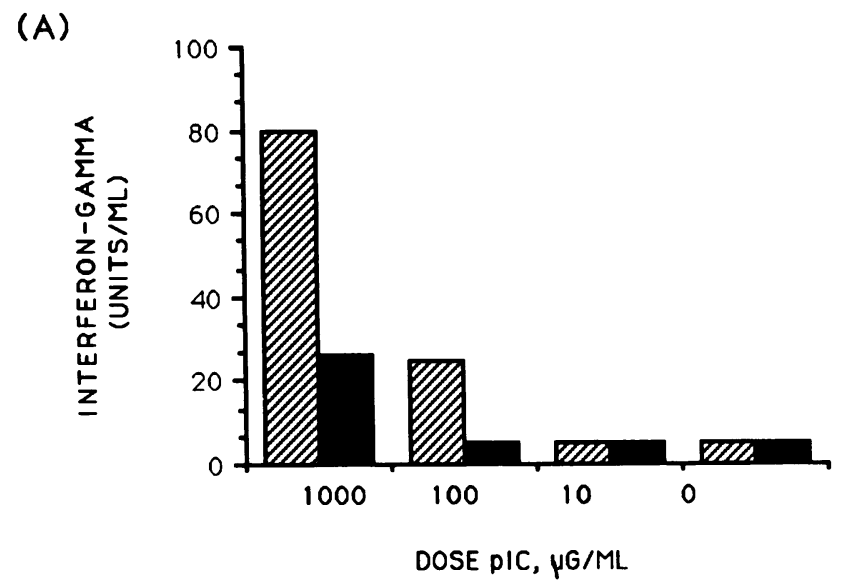

(B)

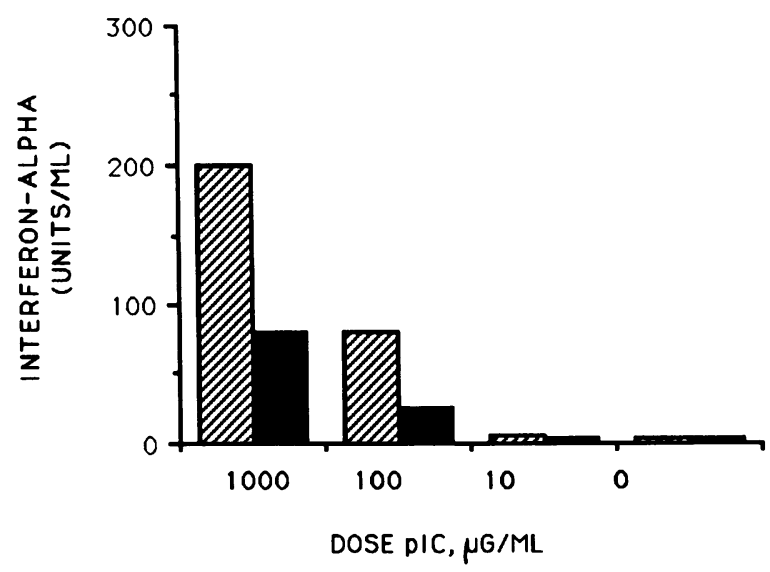

Figure 6. Defective IFN- $\gamma$ and IFN- $\alpha$ production in response to polyIC in peripheral blood lymphocytes from an XP patient. Lymphocytes from XP patient 8 and a normal control were incubated with different doses of polylC for $2 \mathrm{~h}$, washed, and then cultured. After 48 $h$, supernatants were collected and assayed for IFN- $\gamma$ and IFN- $\alpha$ activity by bioassay as described in Methods. $(A)$ IFN- $\gamma$ activity. Representative data from an experiment that was performed three times are shown. ( $B$ ) IFN- $\alpha$ activity. (四) Control cells; ( $\square$ ) XP cells. 
Table III. IFN- $\gamma$ Secretion into Supernatants by Xeroderma Pigmentosum Lymphocytes after Treatment with IFN Inducers: IFN- $\gamma$ Production by Control and XP PBL*

\begin{tabular}{|c|c|c|c|c|c|c|c|c|c|c|c|c|c|c|c|c|c|c|c|}
\hline \multicolumn{12}{|c|}{ A. Bioassay } & \multicolumn{8}{|c|}{ B. ELISA ${ }^{* 3}$} \\
\hline \multicolumn{4}{|c|}{ K562 } & \multicolumn{4}{|c|}{ IL-2 } & \multicolumn{4}{|c|}{ polyIC } & \multicolumn{4}{|c|}{ K562 } & \multicolumn{4}{|c|}{ IL-2 } \\
\hline (Pt. no.) & $\mathbf{X P}$ & Con & Ratio & (Pt. no.) & $\mathbf{X P}$ & Con & Ratio & (Pt. no.) & $\mathbf{X P}$ & Con & Ratio & (Pt. no.) & XP & Con & Ratio & (Pt. no.) & $\mathbf{X P}$ & Con & Ratio \\
\hline & & & $\%$ & & & & $\%$ & & & & $\%$ & & & & $\%$ & & & & $\%$ \\
\hline (4) & 125 & 398 & 31 & (4) & 50 & 80 & 63 & (4) & 199 & 398 & 50 & (4) & 125 & 398 & 31 & (4) & 350 & 470 & 74 \\
\hline (8) & 16 & 100 & 16 & (8) & 80 & 501 & 16 & (8) & 5 & 25 & 20 & (8) & 25 & 80 & 31 & (8) & 90 & 290 & 31 \\
\hline (5) & 0 & 398 & 0 & (6) & 251 & 398 & 63 & (5) & 25 & 80 & 31 & (2) & 16 & 100 & 16 & (2) & 35 & 170 & 20 \\
\hline (7) & 2 & 8 & 25 & (7) & 80 & 251 & 32 & & & & & (1) & 0 & 398 & 0 & (1) & 460 & 750 & 61 \\
\hline \multirow[t]{3}{*}{ (2) } & 0 & 200 & 0 & (2) & 40 & 200 & 20 & & & & & (5) & 2 & 8 & 25 & & & & \\
\hline & & & & (1) & 251 & 398 & 63 & & & & & & & & & & & & \\
\hline & & & $14 \pm 6^{11}$ & & & & $43 \pm 9^{11}$ & & & & $34 \pm 7^{\prime}$ & & & & $21 \pm 5^{1}$ & & & & $46 \pm 11^{* *}$ \\
\hline
\end{tabular}

\begin{abstract}
* Lymphocytes from XP and normal individuals were cultured with medium alone or with the interferon inducers, K562 cells, IL-2 (1,000 U/ $\mathrm{ml}$ ), or polyIC $(100 \mu \mathrm{g} / \mathrm{ml})$, and then incubated for $24 \mathrm{~h}$. Supernatants were collected and IFN- $\gamma$ was assayed (see Methods for details). The IFN levels in the XP and the normal cultures incubated with medium alone were below the level of detection of the assay. ${ }^{\ddagger}$ The data are represented as "raw data" from individual experiments in which induced IFN- $\gamma$ production of XP and control PBL were studied. Since there was variability in IFN- $\gamma$ production in different assays, the data from XP PBL are paired with the normal control PBL from each individual assay (assays on each patient were performed on separate occasions). The data are then summarized as a ratio, which equals (IFN XP $\left._{\text {IFN }} / \mathrm{Ion}_{\mathrm{n}}\right) \times 100$. The ratios of individual experiments are then summarized as a geometric mean \pm standard error of the mean. These data were analyzed for statistical significance as described in Methods. ${ }^{8}$ Note that IFN- $\gamma$ production induced by polyIC was not assayed by ELISA. $P<0.0001$ XP vs. normal. ' $P<0.001 \mathrm{XP}$ vs. normal. ${ }^{* *} P<0.01 \mathrm{XP}$ vs. normal.
\end{abstract}

XP patient number 8 produced significantly less IFN- $\gamma$ and IFN- $\alpha$ in response to polyIC $(10-1,000 \mu \mathrm{g} / \mathrm{ml})$ than did control lymphocytes (Fig. 6). Assay of IFN- $\gamma$ production in response to a single dose $(100 \mu \mathrm{g})$ pIC by two other patients (patients 4 and 5) also revealed decreased interferon production (Table III). We also assayed culture supernatants from lymphocytes from seven XP patients (patients 1, 2, 4, 5, 6, 7, and 8) after exposure to three IFN inducers: K562 tumor cells, IL-2 and polyIC (Table III). There was no difference in the baseline, unstimulated IFN- $\gamma$ levels between the XP and normal lymphocytes. However, after exposure to three different stimuli, lymphocytes from all XP patients produced less IFN- $\gamma$ by bioassay than control lymphocytes (13-43\% of normal). This same pattern of decreased IFN- $\gamma$ production was noted in the ELISA assay for IFN- $\gamma$ released into the supernatant by these cells ( $24-46 \%$ of normal).

Kinetic analysis of IFN production in response to polyIC by peripheral blood lymphocytes from two XP patients (patients 5 and 8 ) revealed decreased or absent IFN- $\gamma$ production at all time points assayed $(8,16$, and $24 \mathrm{~h})$ (data not shown). Production of IFN- $\gamma$ in response to polyIC by PBL from three non-XP skin cancer control patients was equal to that of normal controls (data not shown).

\section{Discussion}

In this study, we identified heterogeneity of XP patients in their expression of constitutive NK cell function. Five of eight XP patients expressed consistently depressed NK cell function, whereas the remaining three patients expressed consistently normal NK cell function. There were no obvious differences with regard to age, clinical features, or numbers of skin cancers between the two groups. Norris et al. $(26,27)$ reported reduced NK cell activity in five XP patients. None of the XP patients they studied had skin cancer whereas all of the patients we studied had skin cancer. A subsequent report by this group described a XP patient with multiple skin cancers who had normal NK cell activity (37). Our finding of heterogeneity of NK cell activity among XP patients with multiple neoplasms indicates that the level of constitutive NK cell activity does not correlate with presence of skin cancer development.

In contrast to XP patients, NK cell activity from all non$X P$ skin cancer patients studied was equivalent to that of normal controls. This is consistent with previous reports that endogenous NK activity is normal in patients with skin cancers (38). This also suggests that the depressed NK activity in XP patients is not a direct result of multiple skin cancers.

We utilized an inducer of endogenous IFN, polyIC, to determine whether NK cells from XP patients would respond with enhanced NK activity $(30,39,40)$. PolyIC enhancement of NK activity is thought to be mediated by production of IFN since in vivo and in vitro NK activity correlates well with IFN levels (1). We found an almost complete failure of polyIC to enhance NK cell activity with PBL from XP patients. This suggested the possibility that impaired IFN production may be responsible for this NK cell defect. Studies of supernatants from XP lymphocytes in response to IFN stimulators demonstrated that defective production of IFN- $\gamma$ and IFN- $\alpha$ was present and may be responsible for the failure of NK enhancement observed in all five XP patients tested. In contrast, PBL from non-XP skin cancer controls responded normally to polyIC by enhancing their NK activity and producing IFN at levels similar to that of normal controls.

LAK cell activity and TNF- $\alpha$ production of peripheral blood lymphocytes from XP patients was normal after IL-2 stimulation. Since the XP lymphocytes had a decreased IFN- $\gamma$ response, these findings are consistent with previous observations that the generation of LAK cells is independent of IFN- $\gamma$ 
(41). Norris et al. (27) also found normal LAK activity in two XP patients. These observations also suggest that the impaired production of IFN by PBL from XP patients may be a specific defect.

Previous in vitro studies of the effects of retinoids on NK cell activity and IFN production suggest that retinoids inhibit these functions (42-46). Although some of our XP patients (patients 1, 2, 3, 5, and 7) were being treated with isotretinoin at the time we assayed their NK cell activity, it is unlikely that our ex vivo study of lymphocytes from XP patients simply reflect the effects of retinoids on NK cell function. First, two of our XP patients (patients 3 and 7) had consistently normal baseline NK cell activity while receiving oral isotretinoin therapy $(0.5 \mathrm{mg} / \mathrm{kg}$ per $\mathrm{d})$. Second, we assayed NK activity of XP patient number 4 before and after initiating isotretinoin therapy $(0.5 \mathrm{mg} / \mathrm{kg}$ per $\mathrm{d})$, and did not observe any change in NK cell function (data not shown). Third, two XP patients (patients 6 and 8 ) who had decreased NK activity did not receive isotretinoin at any time during the study. In addition, lymphocytes from patient 8 also had absent polyIC augmentation of NK activity and blunted interferon production. An explanation for the discrepancies between our results and that of previous studies investigating the effects of retinoids on NK activity may be due to the continuous presence of retinoids in the culture medium in previous studies while we did not add retinoids to our cultures.

NK cell activity has been reported to be normal to increased in patients with skin cancer (38). Assays of NK cell activation as described in our study have not been utilized to examine this aspect of NK cell biology in these disorders. Our studies of unstimulated and induced NK activity in non-XP skin cancer patients suggests that the presence of extensive actinic damage and skin cancer is not the cause of impaired NK function in patients with XP. These data suggest that factors specific to XP, perhaps defective DNA repair, may be responsible for their abnormal NK function.

The therapy of patients with XP has focused on their DNA repair defects. Such patients are counseled extensively in avoiding ultraviolet radiation. Indeed, actinic damage and skin cancers develop on exposed skin. Such cutaneous malignancies are generally managed utilizing surgical treatments. Retinoid therapy has recently been demonstrated to be an effective chemopreventive agent against the development of new skin cancers in XP patients (28). However, the chronic administration of retinoid therapy may be associated with unacceptable toxic reactions (47). The immune deficiency of the XP patients we studied did not appear to be altered by treatment with oral isotretinoin. IFNs are being used experimentally for therapy of advanced melanoma (48) and other skin cancers (49). One of the characteristics of cells that mediate NK activity is the enhancement of cytotoxic activity by certain exogenous cytokines including IL-2 and IFNs $(31,35)$. We found that the ability of NK cells from XP patients to respond to IFN- $\alpha$ was not significantly different when compared to normal controls. Thus, if the decreased interferon production in XP is relevant to the susceptibility of these patients to develop skin cancer, then the administration of IFN may be of benefit in preventing or treating skin cancers. In support of this hypothesis, intralesional injection of IFN- $\alpha$ was found to produce clinical and histological disappearance of multiple cutaneous in situ melanomas in XP patient 8 (unpublished observation).

In summary, our data indicate that XP patients have nor- mal numbers of circulating NK cells, normal LAK cell activity, normal TNF- $\alpha$ production, and normal ability of NK cells to respond to exogenous interferon stimulation. The constitutive NK activity was reduced in five XP patients but normal in three others. However, in all XP patients studied there was a profound inability to increase NK activity by addition of the IFN inducer polyIC. The finding that XP PBL increased NK activity normally in response to exogenous interferon suggested an abnormality in interferon production. We found that IFN- $\alpha$ and IFN- $\gamma$ production by XP PBL was only $13-43 \%$ of normal. Thus, lymphocytes from XP patients appear to have a defect in IFN production after activation as well as a variable defect in the function of NK cells. The combination of specific defects in immune function and a cellular DNA repair defect (which results in a high frequency of UV-induced mutations in skin cells), may render these individuals extraordinally susceptible to the development of skin cancers. It is noteworthy that another cancer-prone, hereditary disease that involves abnormalities in processing DNA damage, Fanconi's anemia, also has abnormalities in lymphokine pathways (50). These findings and the data reported herein suggest that there may be a fundamental connection between the regulation of lymphokine expression and DNA repair genes.

\section{Acknowledgments}

The authors wish to thank Dr. Charlie Evans for his useful discussions and Ms. Margaret Piscitello for her role in preparing the manuscript.

This study was supported by the following sources: Rochester Area Cancer Action, Inc., through the Levin Research Grant, T. Franklin Williams, M.D., Foundation, Inc.-Laura West New Investigator Award, and Rochester Area Pepper Center grant AG10463. Dr. Gaspari was supported by National Institutes of Health First Award 1R29AR40933-01.

\section{References}

1. Welsh, R. M. 1984. Natural killer cells and interferon. CRC Crit. Rev. Immunol. 5:55-93.

2. Talmadge, J. E., K. M. Meyers, D. J. Prieur, and J. R. Starkey. 1980. Role of NK cells in tumor growth and metastasis in beige mice. Nature (Lond.). 284:622624.

3. Talmadge, J. E., K. M. Meyers, D. J. Prieur, and J. R. Starkey. 1980. Role of natural killer cells in tumor growth and metastasis: normal and beige mice. $J$. Natl. Cancer Inst. 65:929-935.

4. Haller, O., M. Hansson, R. Kiessling, and H. Wigzell. 1977. Role of nonconventional natural killer cells in resistance against syngeneic tumor cells in vivo. Nature (Lond.). 270:609-611.

5. Karre, K., G. O. Klein, R. Kiessling, and J. C. Roder. 1980. Low natural in vivo resistance to syngeneic leukemias in natural killer-deficient mice. Nature (Lond.). 284:624-626.

6. Hanna, N., and I. J. Fidler. 1980. Role of natural killer cells in the destruction of circulating tumor emboli. J. Natl. Cancer Inst. 63:801-809.

7. Habu, S., H. Fukui, K. Shimamaura, M. Kasai, Y. Nagai, K. Okumura, and N. Tamaoki. 1981. In vivo effects of anti-asialo GM1. I. Reduction of NK activity and enhancement of transplanted growth in nude mice. J. Immunol. 127:34-38.

8. Pollack, S. B., and L. A. Hallenbeck. 1982. In vivo reduction of NK activity with anti-NK 1 serum: direct evaluation of NK cells in tumor clearance. Int. $J$. Cancer. 29:203-207.

9. Reid, L. M., N. Minato, I. Gresser, J. Holland, A. Kadish, and B. R. Bloom. 1981. Influence of anti-mouse interferon serum on the growth and metastasis of tumor cells persistently injected with virus and of human prostatic tumors in athymic nude mice. Proc. Natl. Acad. Sci. USA. 78:1171-75.

10. Kawase, I., D. L. Urdal, C. G. Brooks, and C. S. Henney. 1982. Selective depletion of NK cell activity in vivo and its effect on the growth of NK sensitive and NK resistant tumor cell variants. Int. J. Cancer. 29:567-574.

11. Hanna, N., and R. C. Burton. 1981. Definitive evidence that natural killer cells inhibit experimental tumor metastasis in vivo. J. Immunol. 127:1754-1758.

12. Pross, H. R., and M. G. Baines. 1976. Spontaneous human lymphocytemediated cytotoxicity against tumor target cells. I. The effect of malignant disease. Int. J. Cancer. 18:593-604. 
13. Vose, B. M. 1980. Natural killers in human cancer: activity of tumor-infiltrating and draining node lymphocytes. In Natural Cell Mediated Immunity against Tumors. R. B. Heberman, editor. Academic Press, New York. 10811087.

14. Robbins, J. H., K. H. Kraemer, M. A. Lutzner, B. W. Festoff, and H. G. Coon. 1974. Xeroderma pigmentosum: an inherited disease with sun sensitivity, multiple cutaneous neoplasms and abnormal DNA repair. Ann. Intern. Med. 80:221-248.

15. Kraemer, K. H., M. M. Lee, and J. Scotto. 1987. Xeroderma pigmentosum: cutaneous, ocular, and neurologic abnormalities in 830 published cases. Arch. Dermatol. 123:241-250.

16. Cleaver, J. E., and K. H. Kraemer. 1989. Xeroderma pigmentosum. In The Metabolic Basis of Inherited Disease, 6th edition. C. R. Scriver, A. L. Beaudet, W. S. Sly, and D. Valle, editors. McGraw Hill, Inc., New York. 2949-2971.

17. Epstein, J. H., K. Fukuyama, W. B. Reed, and W. L. Epstein. 1970. Defect in DNA synthesis in skin of patients with xeroderma pigmentosum demonstrated in vivo. Science (Wash. DC). 168:1477-1478.

18. Lafforet, D., and J. M. Dupuy. 1977. Inhibitory factors of lymphocyte proliferation in serum from patients with xeroderma pigmentosum. Clin. Immunol. Immunopathol. 8:377-384.

19. Dupuy, J. M., and D. Lafforet. 1974. A defect of cellular immunity in xeroderma pigmentosum. Clin. Immunol. Immunopathol. 3:52-58.

20. Berkel, A. I., and O. Kiran. 1974. Immunological studies in children with xeroderma pigmentosum. Turk. J. Pediatr. 16:43-52.

21. Giraldo, G., L. Degos, and E. Beth. 1977. C8 deficiency in a family with xeroderma pigmentosum; lack of linkage to the HLA region. Clin. Immunol. Immunopathol. 8:377-84.

22. Wysenbeek, A. J., and H. Weiss. 1986. Immunologic alterations in xeroderma pigmentosum patients. Cancer. 5:219-221.

23. Salamon, T., M. Stojakovic, and B. Bogdanovic. 1975. Delayed hypersensitivity in xeroderma pigmentosum. Arch. Dermatol. Forsch. 251:277-280.

24. Wysenbeek, A. J., A. L. Pick, H. Weiss, D. Vana, and A. Atsmon. 1980. Tumores rari et inusitati: impaired humoral and cellular immunity in xeroderma pigmentosum. Clin. Oncol. 65:361-365.

25. Goldstein, B., P. Khilnani, A. Lapey, J. Cleaver, and A. Rhodes. 1990. Combined immunodeficiency associated with xeroderma pigmentosum. Ped. Dermatol. 7:132-135.

26. Norris, P. G., G. A. Limb, A. S. Hamblin, and J. L. M. Hawk. 1988 Impairment of natural-killer-cell activity in xeroderma pigmentosum. $N$. Engl.J. Med. 319:1668. (Lett.)

27. Norris, P. G., G. A. Limb, A. S. Hamblin, A. R. Lehmann, C. F. Arlett, J. Cole, A. P. W. Waugh, and J. L. M. Hawk. 1990. Immune function, mutant frequency and cancer risk in the DNA repair defective genodermatoses xeroderma pigmentosum, Cockayne's syndrome and trichothiodystrophy. J. Invest. Dermatol. 94:94-100.

28. Kraemer, K. H., J. J. DiGiovanna, A. N. Moshell, R. E. Tarone, and G. L. Peck. 1988. Prevention of skin cancer in xeroderma pigmentosum with the use of oral isotretinoin. N. Engl. J. Med. 318:1633-1637.

29. Ortaldo, J. R., A. Mantovani, D. Hobbs, M. Rubinstein, S. Pestka, and R. Herberman. 1983. Effects of several species of leukocyte interferon on cytotoxic activity of NK cells and monocytes. Int. J. Cancer. 31:285-289.

30. Koren, H. S., S. J. Anderson, D. G. Fisher, C. S. Copeland, and P. J. Jensen. 1981. Regulation of human natural killing. I. Role of monocytes, interferon, and prostaglandins. J. Immunol. 127:2007-2013.

31. Ortaldo, J. R., and D. L. Longo. 1988. Human natural lymphocyte effec- tor cells: definition, analysis of activity, and clinical effectiveness. J. Natl. Cancer Inst. 80:999-1010.

32. Winer, B. J., editor. 1971. Computational formulas for the $t$ statistic. In Statistical Principles in Experimental Design. 2nd edition. McGraw Hill, Inc., New York, 35-57.

33. Ziegler-Heitbrock, H. W. L., R. Munky, E. Thiel, I. Krebs, and G. Riethmuller. Killer cell activation of human monoblastic leukemia cells as detected with a monocyte-specific target cell. Blood. 65:8-14.

34. Stewart, W. E. II. 1979. Interferon assays. In The Interferon System. Springer Verlag Inc., New York. 13-26.

35. Ortaldo, J. R., N. P. Lang, T. Timonen, and R. B. Herberman. 1981. Augmentation of human natural killer cell activity by interferon: conditions required for boosting and characteristics of effector cells. J. Interferon Res. 1:253262.

36. Ortaldo, J. R., R. B. Herberman, C. Harvey, P. Osheroff, Y. E. Pan, B. Kelder, and S. Pestka. 1984. A species of human interferon that lacks the ability to boost human natural killer activity. Proc. Natl. Acad. Sci. USA. 81:4926-29.

37. Anstey, A. V., C. F. Arlett, J. Cole, P. G. Norris, A. S. Hamblin, G. A. Limb, A. R. Lehmann, J. D. Wilkinson, and M. Turner. 1991. Long-term survival and preservation of natural killer cell activity in a xeroderma pigmentosum patient with spontaneous regression and multiple deposits of malignant melanoma. Br. J. Dermatol. 125:272-278.

38. de LaRocque, L., B. Olej, M. M. Zalis, J. Goulart, and V. M. Rumjanek. 1989. Natural killer activity and skin cancer. Cancer J. 2:383-385.

39. Reynolds, C. W., M. J. Brunda, H. T. Holden, and R. B. Herberman. 1981. Role of macrophages in in vitro augmentation of rat, mouse, and human natural killer activities. J. Natl. Cancer Inst. 66:837-42.

40. Wiedbrauk, D. L., and G. R. Burleso. 1986. Production and characterization of poly(I): poly(C)-induced rat interferons in vitro. J. Interferon Res. 6:281-295.

41. Bloom, E. T., J. T. Babbitt, and K. Kawakami. 1986. Monocyte-mediated augmentation of human natural killer cell activity: conditions, monocyte and effector cell characteristics. J. Immunol. 137:172-78.

42. Abb, J., H. Abb, and F. Deinhardt. 1982. Retinoic acid suppression of human leukocyte interferon production. Immunopharmacology. 4:303-310.

43. Bremin, O., J. Ashby, and J. Rhodes. 1984. Inhibition of antibody-dependent cellular cytotoxicity and natural cytotoxicity by retinoic acid. Int. Arch. Allergy Appl. Immunol. 75:2-7.

44. Blalock, J. E., and G. E. Gifford. 1977. Retinoic acid induced transcriptional control of interferon production. Proc. Natl. Acad. Sci. USA. 74:53825386.

45. Rhodes, J. 1983. Human interferon action: reciprocal regulation by retinoic acid and beta-carotene. J. Natl. Cancer Inst. 70(5):833-837.

46. McKerrow, K. J., R. M. Mackie, M. J. Lesko, and C. Pearson. 1988. The effect of oral retinoid therapy on the normal human immune system. Br. J. Dermatol. 119:313-320.

47. DiGiovanna, J. J., R. K. Helfgott, L. H. Gerber, and G. L. Peck. 1986. Extraspinal tendon and ligament calcification associated with long-term therapy with etretinate. N. Engl. J. Med. 315:1177-1182.

48. Gunderson, S., and A. Flokkmann. 1991. Interferon plus dacarbazine in advanced malignant melanoma. Eur. J. Cancer. 27:220-221.

49. Bernasconi, C. 1990. Clinical use of alpha-interferon in onco-hematology: conclusions and prospects. Haematologica. 75(Suppl. 4):82-84.

50. Roselli, F., J. Sanceau, J. Wietzerbin, and E. Moustacchi. 1992. Abnormal lymphokine production: a novel feature of the genetic disease Fanconi anemia. I Involvement of interleukin-6. Hum. Genet. 89:42-48. 